УДК 82.02Модернізм(474)

\title{
THE SECONDARY IN CONCEPT OF RESISTANCE AND PROCESSES OF MODERNISM: RETHINKING BALTIC MINIMALISM
}

\author{
Юрате Ландсбергіте-Бехер \\ orcid.org/0000-0003-2356-7264 \\ jurate128@yahoo.de \\ Відділ історії музики та театру \\ Литовський інститут культурних досліджень \\ Saltoniškių g. 58, 08105, Vilnius, Lithuania
}

\begin{abstract}
Анотація. Балтійська сучасна ідентичність базується на Опорі меншого і натхненна пошуком вторинного, вцілілого у повоєнній історії. Сила Опору була зруйнована й перетворилася в особливе явище культури, де домінує пасіонарніть другорядного, меншого, що створює важливу метафору „сну під землею”, архетип „Я”, здатний підніматися з глибини, відповідний природній стихії. Ця сила „сну в землі” надихнула балтійський модернізм, в якому другорядне й основне чітко розділено: другорядне ліворуч, а все, що кодує вираження людини i нації, - праворуч. Метою балтійського мінімалізму, який шукає меншість, торкається темної сторони часів, є драматургія воскресіння (крім того, секунда в музиці означає інтонаційну клітину або другорядний інтервал, „один крок” від інтервалу пріма. Це все сприяє процесу трансформації. Пасіонарний другорядний виражає свій протест у творчій роботі зі „сталою точкою повороту світу” (Т. С. Еліот).
\end{abstract}

Ключові слова: другорядне, влада, пасіонарність, опір, трансформація, модернізм.

\section{The factor of historic shock.}

The geopolitical catastrophe experienced by Lithuania during the World War II - occupation of the Baltic States, done by the Soviet Union became a special probation of their society. The secondary survivor was lef in fields of the epoch "war after war" with its consequences. National identity, which had to be destroyed, indeed gained alternative forms of

(C) Ландсбергіте-Бехер Ю., 2017 
survival as a minor, secondary natural power. The State surface sank in the dark and had to resurrect. The preconditions for that was the organized resistance, the power of second with fight "After" war which had the features of national army and informal state: the Declaration of the Constitution by liberation movement in 1949, the declared president's institution, related to the general Jonas Žemaitis-Vytautas (who was later inprisoned and killed in Lubianka, Moscow). These complex of "war after war" were special circumstances marked by real, although then not coming true hopes, "waiting for America", when the culture, literature and music took their course of sleeping survivor and his alternative or secondary development. At that time, deeply critical forms of existence awoke on the other side of the ocean: prayers, laments, psalms and the "bell calls" used to be the nation's resurection call from the depths of loss [12, p. 256].

In literature was expressed the so-called catastrophic modernism: the works of the poets emigrants Algimantas Mackus (1932-1964), Henrikas Nagys (1920-1996), playwrights Antanas Škèma (1911-1961), Algirdas Landsbergis (1924-2004).

\section{Global expressed Prayer and finalism}

It is the poetry and dramaturgy, speaking about the state, deleted from the map, lives of enslaved nations and orfans, left utterly alone and speaking "not true language".

Death makes destroyed states, deleted in the maps up to the seas

Sings the song black Maria

In the language of lilies, ice and rain.

A. Mackus. Chapel B [14, p. 140].

The minor groups live is comparible: as blacks in slavery and Baltic nations in occupation.

At the same time, here lies the impulse of the transformation of modernism - renewed nation's consciousness: the world is overturned space, demanding the right mission to save the minor, the second, the right, the passionare one.

\section{The genre of the second.}

The main genre here becomes the passacallia,procession dance 
developed form in music and "the call from the depths the prayer turns to De profundis, to the paradigm of the struggle with the los behind the true existence. The road for the Self to come back is the universal way returning home, the transformation into a clear horizontal line. It is possible to explain, how the secondary straightens this road in to level of horizontal and Enlightening.

The eternity via horizontal became the prospect line of Baltic minimalism: staying low and monoton by rhytms in music with a hidden deep rising power [6, p. 383].

The genre transformation in music is from barock passacallia to orient mandala

This finalism becomes the discourse of modernisation pain fully globalised in emigrants poetry:

\section{Enraged God in the middle of the ritual}

Trowns the Saving to the mass [14, p. 135].

The image of land is changed by its los - empty coast, ship, sailing, shore, ocean. In this way, from the facture of the particulars, one goes to the visual of infinity, rhythm pulsation and limitless sound space in music. Here one can see the absolute's graphics - "the final thrown in front on stage" [14, p. 137], in the situational image of which there emerges the transcendental landscape (K. Jaspers) and other projections of the visual as power of secondary aspect moderating modernism.

The transformed prayer of passionary second and call from the depths also erupt in the Lithuanian and Latvian music of the $6-7^{\text {th }}$ decade. It is "Evening's meditation" (Boston, 1966) by the emigrant Julius Gaidelis (1909-1983), composed for the celebration of religious congress of the Lithuanian emigration in U.S.A., intended for the dedication of Šiluva Maria Chapel in the Cathedrale of Enslaved Nations in Washington D.C. (It was performed by the organist Vytenis Marija Vasiliūnas.)

"Evening's meditation" is an exceptional work of pain and plainsong-pray for organ - lament rising, from the depths of the dark, similar to M. Reger's Passacaglia, distinguished by the dramaturgy of four culmination waves, which next one higher than others, as well as choral lamentations, ending in the coda of dawning and the echo of the bell calls. It is the suggestion of the depths of the pain of the excluded, 
the left over secondary with his passion for the rising power headring to light and Enlighting. In regard to modernism, here opens the perspective of audio-visuality and sacral mistery. And there is the source of eternal Baltic identity: the minority passion for Magnificient power [11, p. 99].

One can differently describe the work for organ Quaternio latviensis (1968, Münster) of another creator of the Baltic emigration Latvian composer Longins Apkalnis (1923-1999). After feeling some especially significant sources of the development of modernism here folklore intonation, the concrete interval of the second in music language and minimalism as a style of the second and the already mentioned apocalyptical-catastrophic finalism with the conception of break down collision. Apkalnis also develops a philosophical dramaturgy of four archetypes as the future projection of the Self in Baltic minimalism:

I. Deconstruction (accatasterendo)

II. Glowing dark (buio lustrando)

III. Simplifying (scempiato)

IV. Sad movement (mozione lugubre).

It is a real intensive symbiosis of modernism in minor germs and sadness of geopolitical drama, opening the magnificient feature of catastrophic modernism. The ideas created the way of the Baltic minimalism phenomenon in music [10, p. 31]. It synchronises both with the psychotherapy of damaged archetypes described by the father of psychoanalysis C. G. Jung (1875-1961) and the dramaturgy of the Self (sleeping in the dark subconsciousness) coming from it [8, p. 25].

The conception of the secondary way rising from the excluded is related to the universal Ego and the trajectory of the axis of the Self. This idea determined the psychotherapeutic orientation of the Baltic modernism and the turn to transcendental escape, to the "other space", including the image of secondary poet fighter for the nation rights and the paradigm of the unlimited.

\section{Resistance and the conception of break down}

If prayer transformations lead to the sacrality (the parabole of the eternity) in the Baltic modernism, then the signs of resistance power of the secondary in poetry and music open another perspective - the conception of the break down or deconstruction in totalitarianism system. 
Metaphoric language of music gestures means maximum concentration of declaration, the power of impulses, reaction of protest, evoking transformation, movement termination, a break and the falls of structure.

Such gestures and signs of breakdown filled music landscape can be seen in several music works, also related to the prayer, lament, call from the depths and ringing bells.

Dawn. It is the sonata for organ Nr. "Prayer for Lithuania" (1980) by Teisutis Makačinas $(* 1938)$ and Musica serva $(1988)$ by latvian Peteris Vasks (*1946), two, during the Soviet period not known, unpublished and almost nowhere publicly performed works. But in them, one can see this aforementioned gathering of resistant gestures and signs (still named as the figures of music rhetoric), protest of turned down secondary, determining the inspirations of the Baltic modernism [9, p. 243]. One of the essential factors here - dramaturgy of break is the language of perspective in "sound space" or sonorism style. The field of its leitmotifs, similarly to "Evening's meditation" by J. Gaidelis, are opened by darkdepths of sound traces (retained sound clusters, implicating nondescript vibration of low overtones). The gesture of push is also characteristic as interval full of tension, its break and impulse. Musica serva as well as "Prayer for Lithuania" have a similar scenario of the beginning, but later, the work by P. Vasks opens in the motion course of brave sonoristic "battlefield" of modernism, meanwhile the work by T. Makačinas "Prayer for Lithuania" stays in the frames of folklore stylistics and laments, close to minimalism. "Prayer for Lithuania" is based on two angular collums of Lithuanian style: folklore lament and church hymn (chorale harmony) metaphor. A characteristic correlation of T. Makačinas with catastrophic modernism of the emigrants easer on plainsong intonation of folklore lament and the development of its lamentations, growing into the intensifying flow of church psalm, bells calls and sutartines (Lithuanian folk songs with developed elements of polyphony). It is a structural principle of "Prayer for Lithuania", terminating in culmination which can also be approached as the sign of break in collision conception.

The battle. Peter Vask's Musica serva (1988) is one of the brightest examples of break down conception. Full of signs of resistance and protest calls - the whole of "touching darkness" music grows into a powerful poem of resistance in sounds: cluster of the dark, impulses - 
wails, laments, cryes and screams, fragments of chorale psalm, ringing bell, battle fanfares, then collapsing structure falls in apocalyptical stagnation of an nondescript din of vibrations, bells and silence. Such P. Vask's course of defragmented, destroyed and transformed quasi passacaglia form of rising from the depths creates phenomenological drama, characteristic to the apocalyptical or catastrophical character of the Baltic modernism. Here lies a strong gene of resistance and perception of own mission performing by secondary survivor: to conceptualise this phenomenon globally, to spread it universaly, to provide the meaning of minority as philosophical existencial paradigm. In this way, in music dramaturgy, there emerges the resistant power encoded in the gestures of its expression, changing the hierarchy of systematic conceptions. Or the image of destruction of the chorale temple, which will inspire the transformation of postmodernism. It can be explained and localised as wild, nondescript.

The so called pagan modernism [7, p. 15] is the phenomenon of counter-push of the replaced, crushed archetypes, the phenomenon of the return from the dark, to which it is really important to shock the consciousness of nation and to change the direction of thinking Lithuanian composer. B. Kutavičius speaks about that openly: "I want to "kill" the listener with sounds, make him to walk tottering" [5, p. 73]. In B. Kutavičius's organ sonata "Ad patres" according to the cycle of paintings by M. K. Čiurlionis (1875-1911) "Funeral symphony" (1906), we can see a dramaturgy case of passacaglia and break down conception as absolute triumph of the dark.

Silence. An especially bright gesture for the system to break down made by as creative secondary cultural resistance is one more piece of Baltic modernism, basically emphasizing a forming concept of the Baltic minimalism. It is Onute Narbutaitè's (*1956) "Road to the silence" (1981) for organ, named by P. Vasks as "the symbol of our generation's musical resistential way". It uncompromisingly gathers the paradigmatic line of music language: the rising melody of silenced second with intersection of sacrality and demonic turns. The expression of sacrality is the metaphor of gregorianic melody in introduction and code post-apocalyptical end, meanwhile the demonic jump in to action is fulfilled by brutal rhythmical steps in basses, dynamic clusters (sound brush) and falls of breaking factures. But the most important impulse of the dramaturgy of "Road to 
the silence" is gathered by the dynamism totalitarian push of the virtuos allmyghty sound of Tutti, all organ voices - cluster through all keyboard manuals even evoking the elbows.

Singing silence, coming after, and the return of "the road to silence" as gregorianic melody is approached as Enlightening, entering a new sacral space. Such creative dramatic transformations took the correlations of the Lithuanian music modernism in post-war world of resistance and protest era, when the society had to be shocked to make its choices, to awayke its consciousness, to hear the destinies of those were left alone and who stayed behind in the silence of the dark. O. Narbutaitè's "Road to silence" (1981) was one of such eloquent opuses of music. Meanwhile poetry word counted on the metaphor to rise its secondary power because of discourse about globalisation or lithuanising the globalisation. Looking at such examples of resistance and sleeping power of minor in poetry, firstly there arise the examples of the verses of the rebellious "last pagan" poet Sigitas Geda (1943-2008). Precisely S. Geda tells the essence of the Baltic phenomenon: "A red dream sleeps in the roots of the oaks" ("Thrush", 1968) [4, p. 77]. This pantheist spirit, related to the nature, is especially characteristic to the Lithuanian mentality (last European pagans). It provided for the Lithuanian modernism a special mix of archaic originality and power of the patience of nature by staying behind, close to Scandinavian sagas, runes and new post-apocalyptical mystery of survival, which the world looks avidly for.

The texts of Sigitas Geda open the break downs of historic catastrophe in Baltics, which crack the system of the verbal and the visual field of unreal identity of Self. It is "Unfinished drawing in the street":

Earth, ploughed by excavators, expose beautiful faces of dead nations [3, p. 25].

Again, a phenomenal strength of the Baltic modernism becomes Caucasus, source of resistances harbouring small nations, deflecting the apocalyptical spaces and possibility to reborn.

It should be noticed that the texts of poetry tell about the perspective to survive the genocide of the nations, drama of existence, natures, infinity, becoming an eternal part of the world. S. Geda writes: 
There is a sea in Asia

There lie snakes in water...

Psalm from "Japanese seas", 1972 [3, p. 27].

The image of the Soviet Union in the poetry by S. Geda is "the red sea",...., "dragon's jaws", "excavators".

Resistant turn in poetry happens when the destiny of the nation merges and opens as the universal unity of spirit:

Blue angel flew

And red clay jugs

Watered somewhere by Caucasus

Filled with Armenian blood... [4, p. 105].

Such fly of the Lithuanian poetry is specific - global, modern, pain of destiny with connection of the replaced nations, archetypical stone of the unright divided millennium in two sides of iron wall.

Then salvation depends on the conception of the system break down, which is really well spread in the creation of the Lithuanian composers and poets of post-war and liberation epochs in music dramaturgy.

\section{Search for "Other space".}

The dramatic intensity the Lithuanian modernism is demonstrated by the art works, too. It is the constructed painting of Vincas Kisarauskas's (1934-1988) with added pieces of cracked blocks strokes and beats, demonstrating the landscapes of structural remains of destruction and anti-humanity, as if encoded piece of K. Jaspers's "transcendence landscapes" [1, p. 565], leading to the nothingness and emptiness of totalitarianism.

Such fatal intensity of the consciousness of the Lithuanian art was that impulse for break and action of break down conception drama (search of replaced archetypes in the depths of the dark). It can be stated, there are roots for the phenomenon of the Baltic modernism, the touch with the dark and the conception of liberation of the Self from the depths of los with a help of the Second. Therefore, many authors fix structural remains, shreds, chips, crumbs, drops, cells turning to the horizontal. It is told by the tittles, for exemple, the oratorio by Onute Narbutaite "Shred to my city", "Centones meae urbi" (1998), Richard Kabelis "Tris-Tan" (2009), 
Rytis Mažulis "Schizmos" (2007), Feliksas Bajoras "Duo-Interludia" (2000), Bronius Kutavičius "Reminiscences" (1988), Ramūnas Motiekaitis "Pine listening" (2005). It is the fragmentation of the structure and opening of the vision of unlimited freedom and eternity for the second, on purpose of penetrating another space opening beyond. It is the turn of the Baltic modernism phenomenon to transcendence, it is also related to the sacral dimension of mentality and the sense of retrospective brought by the waves of geopolitical drama. The necessity for the survivors of having "another space" was globally sensed and verbalised by Czeslaw Milosz (19112004), Lithuanian roots polish poet - Nobelist [15, p. 3].

\section{The steepy way: rethinking and renewing rights of the occupied nations - special mission of the Baltic minimalism}

It can be stated that most inspiring exemple, the paradigmatic work of the phenomenon of the Baltic minimalism and modern Balticity is the music piece, created by the Latvian composer Aivars Kalejs (1951) "Via dolorosa" for organ solo, dedicated to the victims of the Soviet occupation in Baltics and for the memory of the families not returning from the deportation in Siberia. The work implies a stagnated visual secondary step in music: slowly dynamised space, pulsing in the syncoping rhythm of low life-death basis, what reminds Steve Reich (*1936) "Different trains" - the image of the known death trains to Auschwitz. The music form is there the passacaglia again simply transferred in phenomenal cold space vision.

There opens a unique Baltic way of beauty and treath of eternity in the relation with nature's universum, denying the mechanical nihilistic purity of the rhythm pulsation and deadly plane landscape and transforming it to a growing vertical dimension. It is a horizontal implementing the mystery of transcendence. In this connection of the Baltic and afar North horizon, rhythm monotony and prayer, there opens the phenomenon of to transcendental landscape.

A. Kalejs's "Via dolorosa" (1990) concentrates the purified language of the rhythm-intonation cells to a unified flow, including not only the musical dimension, but also a historic, discourse of unright and existential philosophy geopolitical drama, static image getting through a psychoanalytical axis of the replaced archetype of Self in depth and 
shadow. "Via dolorosa" has a sacral, psychological and politological implication, basically, it is the sign of Baltic minimalism rising dimension for eternity postappocapyltical style in music, including the area of the symbols of the Baltic relation to nature and Christianity and calling about minor nation survival, the resurection phenomenon invading the global modern discourse. "Via dolorosa" is the exemple of this kind musical vision in Baltic minimalism.

\section{The paradigm and the road}

It should be noticed that one of the most significant archetypes of human civilisation - the road or the way - is especially comprehensively expressed in Baltic minimalism, precisely with the works of the Lithuanian, Latvian and Estonian and Polish [2, p. 16] composers. Here, it is worth naming the most influential examples of the archetype dimension in organ and other choral or instrumental music. These are:

Arvo Pärt (*1935) Trivium (1976) Fratres (1977), Tabula rasa (1976), Annum per annum (1980);

Bronius Kutavičius (*1932) Last pagan rituals (1978), Ad patres (1984);

Teisutis Makačinas (*1938) Prayer for Lithuania (1980);

Onute Narbutaite (*1956) Road to the silence (1981);

Vidmantas Bartulis (*1954) Prophet (1982);

Algirdas Martinaitis (*1950) Awakening of the last night blossoms (1974), Clavier of live water (1983), Cantus ad futurum (1982);

Imants Zemzaris (*1951) Field. Mandala (1986);

Gracijus Sakalauskas (*1955) Domine, clamavi ad te... (1984);

Peteris Vasks (*1946) Musica serva (1988), Landscape with the birds (1980), Te Deum (1990);

Aivars Kalejs (*1951) Via dolorosa (1990);

Jonas Tamulionis (*1949) Prayer (2000).

All these works have one feature - they implement the secondary levelled line as the one of the Baltic minimalism: the paradigm of the way from the dark to the light, entrenching as the fundamental image of interdisciplinary art language, audio-visual projection, devoted to a special mission of rising secondary or alternative power what also has a political meaning - nation withdrawal to full-rate life of the state in free space.

This is reflected by the structural features of music and poetry, its 
signs language [17], methaphors and their meanings, as well as the tendency to transformation of minority to their aim for other space safe, immune, break resistant area.

\section{Conclusions}

The features of the music style of the Baltic minimalism (as the style of minority and of the passion of the secondary) tell about a deep correlation with the tradition of the resistance, denieyng Soviet occupation in Lithuanian culture. First of all, these features showed themselves in the literature and music of the post-war epoch emigrants poetry, later inspired a specific modernism transformation in the Baltic minimalism. These impulses have their expression, like:

1) prayer transformation (in poetry and music),

2) call from the depths - impulse for the rising in dramaturgy, using renewing passacaglia with a help of the second interval step rising in to transcendence,

3) projection of the dark and the light: glowing shining dark space,

4) rhythm monotony - trajectory of the processes from the secondary step to big wave transformation,

5) break-down conception: culmination break after reaching the wave apocalypse - the system is broken as well as a structure, then the parts of the whole changed their course. The concept of small piece from the part changing the whole,

6) conception of silence entering: resistance to social pathetic, ideology, internal activation of archetypical essences, the so called "road to silence",

7) conception of the second, the soft power or alternative way to power: step in to universal space, emptiness, return home, opening the perspective of the transformation to the Self. The secondary survivor, is overturning the concept of magnificieant maximalistic modernism in to minimalism.

It can be stated that the Baltic phenomenon in music, inspired by secondary survivor (or so called "second Lithuania") passion for the archetypes of resistance, replaced pathetic surfaces, experienced their reaction for breakdown, leading to the system breaking. Thus the Baltic modernism as minimalism or the style of minority was born of hiding in 
the dark, which, differently from the Western European individualistic will of power and hedonistic "history endings", other game acting streams of postmodernism, indeed returned the beginning of history to the present, to be more precise, revealed its whole - first and second layers related to fragmentation and power of ich dimensions. It led the Baltic minimalism to horizon of sacral modernism - via dolorosa in train rhythm responding "Different trains" by Stive Reich, its syncopic pulsation. There are acting the semantics of the eternal return of road important to the "secondary world", so called East Europe, Orient and Baltic about their majesty images. It offers or exemple of the culmination wave in art vision, painted by M. K. Čiurlionis (1875-1911) cyclus "The Sea" Finale (1907). This image calls determination to power vertical in ever horizontal Baltic identity, what inspires the secondary, the leftover minority to create the alternative concept of modernity with a silenced point to turn the world.

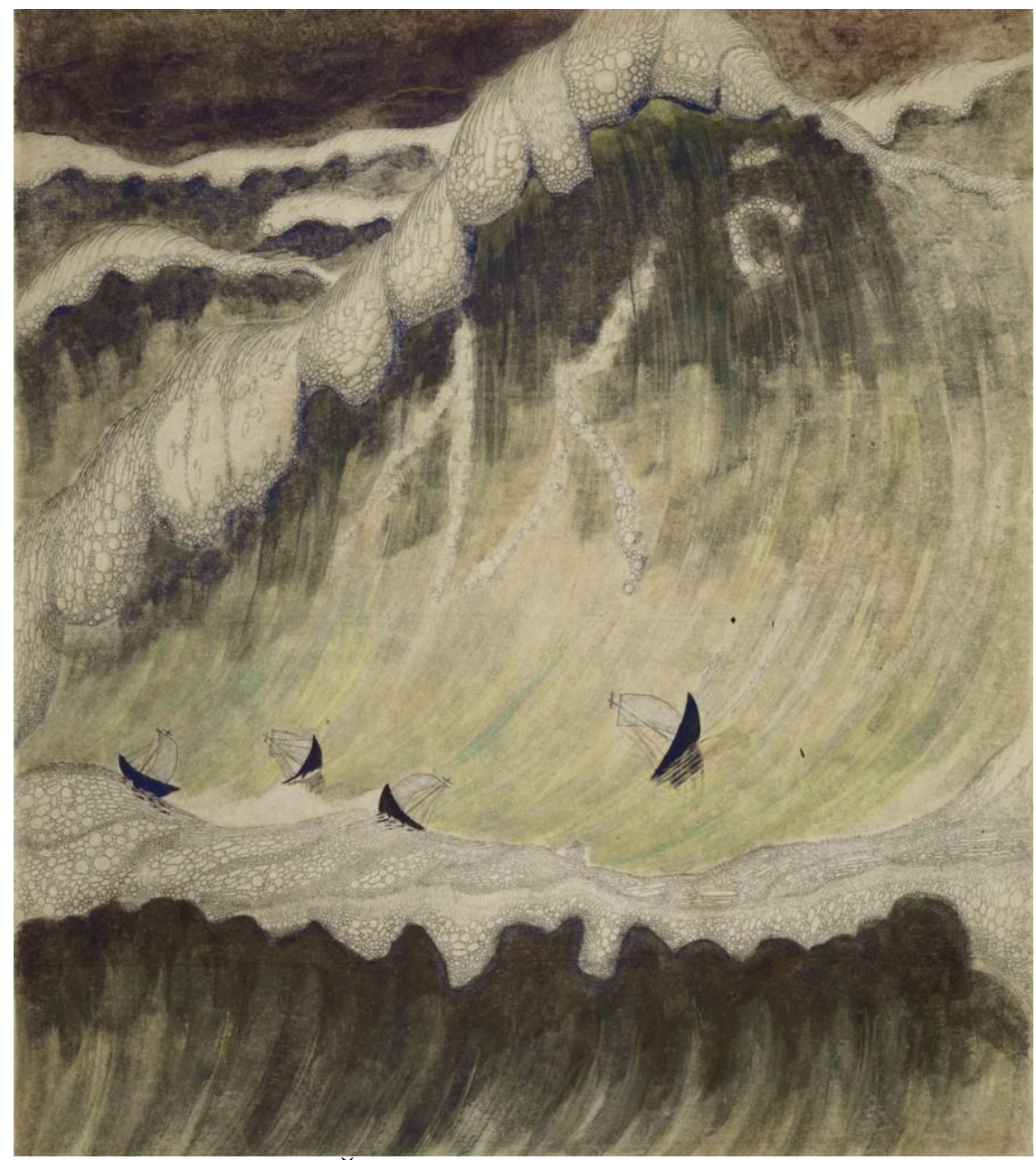

M. K. Čiurlionis “The Sea. Finale” 
1. Andrijauskas, Antanas. Grožis ir menas / Antanas Andrijauskas. - Vilnius : Vilniaus dailès akademijos leidykla, 1995. - $702 \mathrm{p}$.

2. Dzielo muzyczne i jego archetyp (2) = The Musical Work and its Archetype (2) / Ed. A. Nowak. - Bydgoszcz : Akademia muzyczna im F. Nowowiejskiego, 2006. $-268 \mathrm{p}$.

3. Geda, Sigitas. Septynių vasarų giesmès / Sigitas Geda. - Vilnius : Vaga, 1991. - 108 p.

4. Geda, Sigitas. Varnėnas po mėnuliu / Sigitas Geda. - Vilnius : Vaga, 1984. $234 \mathrm{p}$.

5. Gaidamavičiùtè, Rūta. Nauji lietuvių muzikos keliai / Rūta Gaidamavičiūtè. Vilnius : Lietuvos muzikos ir teatro akademija, 2005. - 407 p.

6. Grožio fenomenas kultūroje $=$ The Phenomenon of Beauty in Culture / Sud. Rūta Brūzgienè. - Vilnius : Lietuvių literatūros ir tautosakos institutas, 2012. - 732 p.

7. Jasinskaité-Jankauskienè, Inga. Pagoniškasis avangardizmas. Teoriniai Broniaus Kutavičiaus muzikos aspektai / Inga Jasinskaitè-Jankauskienė. Vilnius : Gervelè, 2001. - 261 p.

8. Jung, Carl Gustav. Beitrage zur Symbolic des Selbst / Carl Gustav Jung. Olten : Walter Verlag, 1976. - 340 S.

9. Landsbergytè, Jüratè. Baltiškoji Savastis: archetipiniai rezistencinès kovos bruožai nežinomoje sovietmečio vargonų muzikoje (T. Makačino "Malda už Lietuvą", P. Vasko "Musica serva") / Jūratė Landsbergytė // Menotyra. Studies in Art. - 2014. - Vol. 21. - № 3. - P. 243-256.

10. Landsbergytè, Jüratè. Baltiškas minimalizmas: intonacinè ląstelè istorijos dramoje / Jürate Landsbergytė // Acta academica artum Vilnensis / Sud. Agnè Narušyte. - 2010. - T. 58. - P. 31-41.

11. Landsbergytè-Becher, Jüratè. M. K. Čiurlionis ir baltiškas minimalizmas / Jūratè Landsbergytė-Becher // Čiurlionis ir pasaulis = Čiurlionis and the World / Sud. Rimantas Astrauskas. - Vilnius : Lietuvos muzikų rėmimo fondas, 2011. - P. 98-107.

12. Landsbergytè, Jüraté. Maldos transformacijos emigrantų kūryboje: katastrofinio modernizmo gestai. A. Mackaus poezijoje, J. Gaidelio ir L. Apkalnio vargonų muzikoje / Jūratė Landsbergytė // Menotyra. Studies in Art. - 2013. - Vol. 20. - № 3. - P. 255-272.

13. Mackus, Algimantas. Poezija / Algimantas Mackus. - Vilnius : Vaga, 1972. $167 \mathrm{p}$.

14. Mackus, Algimantas. Trys knygos: Jo yra žemé. Neornamentuotos kalbos generacija. Chapel B / Algimantas Mackus. - Vilnius : Baltos lankos, 1999. $172 \mathrm{p}$.

15. Milosz, Czeslav. Tèvynès ieškojimas / Czeslav Milosz. - Vilnius : Baltos lankos, 2011. $-275 \mathrm{p}$.

16. Modernism and Music. An Anthology of Sources / Ed. By Daniel Albright. Chicago : The University of Chicago Press, 2004. - 428 p. 
17. Tarasti, Eero. Signs of music : a guide to musical semiotics / Eero Tarasti. Berlin, New York : Mouton de Gruyter, 2002. - 224 p.

\title{
ВТОРОСТЕПЕННОЕ В КОНЦЕПЦИИ СОПРОТИВЛЕНИЯ И ПРОЦЕССОВ МОДЕРНИЗМА: ПЕРЕОСМЫСЛЕНИЕ БАЛТИЙСКОГО МИНИМАЛИЗМА
}

\author{
Юрате Ландсбергите-Бехер \\ orcid.org/0000-0003-2356-7264 \\ jurate128@yahoo.de \\ Отдел истории музыки и театра
}

Литовский институт культурных исследований

Saltoniškiu g. 58, 08105, Vilnius, Lithuania

\begin{abstract}
Аннотация. Балтийская современная идентичность базируется на Сопротивлении младшего и вдохновлена поиском вторичного, уцелевшего в послевоенной истории. Сила Сопротивления была разрушена и превратилась в особое явление культуры, где доминирует пассионарность второстепенного, меньшего, что формирует важную метафору „сон под землей”, архетип „Я”, способные подниматься из глубины, соответствующей природной стихии. Эта сила „сна в земле” вдохновила балтийский модернизм, второстепенное левизны, кодирующее выражение человека, и нации справа. Целью балтийского минимализма, довлееющему к меньшинству и касающемуся темной стороны времен, является драматургия воскрешения (так, секунда в музыке означает интонационную микроклетку или второстепенный интервал, „один шаг” от интервала прима). Это все способствует процессу трансформации. Пассионарное второстепенное выражает свой протест в творческой работе с „постоянной точкой поворота мира” (Т. С. Элиот).

Ключевые слова: второстепенное, власть, пассионарность, сопротивление, трансформация, модернизм.
\end{abstract}

\section{THE SECONDARY IN CONCEPT OF RESISTANCE AND PROCESSES OF MODERNISM: RETHINKING BALTIC MINIMALISM}

\author{
Jüratè Landsbergytè-Becher \\ orcid.org/0000-0003-2356-7264 \\ jurate128@yahoo.de \\ Department of Music and Theater History \\ Lithuanian Culture Research Institute \\ Saltoniškiu g. 58, 08105, Vilnius, Lithuania
}


Abstract. The Baltic modern identity is based on Resistance of minor and inspired by looking for secondary survivor in the post-war history. The power of Resistance was crushed and became overturn into a special phenomenon of culture, dominated by passion of the second, the minor, creating the important metaphor of "sleeping underground" ("in the roots of oak"), the archetype of Self being able to rise from the depths, corresponding to the natural element. This "sleeping in the earth" (underground) power inspired the Baltic modernism, the second left, what encodes the expression of the human and nation right. The destination of Baltic minimalism, looking for minority, who touched the dark side of times, is the dramaturgy of resurrection (besides, the second in music means intonation cell or the minor interval of second, the "first step out" from the prima). This all is going to create the process of transformation. The passionate secondary expresses his protest in creative work with "still point of turning world" (T. S. Eliot).

Key words: secondary, power, passion, resistance, transformation, modernism.

\section{References}

1. Andrijauskas, Antanas. Grožis ir menas [Beauty and Art]. Vilnius, 1995, 702 p.

2. Dzielo muzyczne i jego archetyp (2) = The Musical Work and its Archetype (2). Ed. A. Nowak. Bydgoszcz, 2006, 268 p.

3. Geda, Sigitas. Septyniu vasaru giesmès [Psalms of seven summers]. Vilnius, 1991, $108 \mathrm{p}$.

4. Geda, Sigitas. Varnénas po menuliu [Starling under the moon]. Vilnius, 1984, $234 \mathrm{p}$.

5. Gaidamavičiūtè, Rūta. Nauji lietuviu muzikos keliai [New ways of the Lithuanian music]. Vilnius, 2005, $407 \mathrm{p}$.

6. Grožio fenomenas kultüroje = The Phenomenon of Beauty in Culture. Ed. by Rūta Brūzgienè. Vilnius, 2012, 732 p.

7. Jasinskaitè-Jankauskienè, Inga. Pagoniškasis avangardizmas. Teoriniai Broniaus Kutavičiaus muzikos aspektai [Pagan avangarde. Theoretic aspects of Bronius Kutavičius Music]. Vilnius, 2001, 261 p.

8. Jung, Carl Gustav. Beitrage zur Symbolic des Selbst. Olten, 1976, 340 S.

9. Landsbergytè, Jūratė. Baltiškoji Savastis: archetipiniai rezistencinės kovos bruožai nežinomoje sovietmečio vargonų muzikoje (T. Makačino "Malda už Lietuvą", P. Vasko "Musica serva") [Baltic Self: archetypical features of resistance fight in the unknown organ music of the Soviet times (T. Makačinas "Payer for Lithuania", P. Vask's "Musica serva")]. Menotyra. Studies in Art, 2014, vol. 21, no. 3, pp. 243-256.

10. Landsbergytė, Jūratė. Baltiškas minimalizmas: intonacinè ląstelè istorijos dramoje. [Baltic minimalism: historical drama of intonation cell]. In: Acta academica artum Vilnensis. Ed. by Agnè Narušytè. Vilnius, 2010, vol. 58, pp. 31-41. 
11. Landsbergytė-Becher, Jūratè. M. K. Čiurlionis ir baltiškas minimalizmas [M. K. Čiurlionis and Baltic minimalism]. In: Čiurlionis ir pasaulis = Čiurlionis and the World. Ed. by Rimantas Astrauskas. Vilnius, 2011, pp. 98-107.

12. Landsbergytè, Jūratè. Maldos transformacijos emigrantų kūryboje: katastrofinio modernizmo gestai. A. Mackaus poezijoje, J. Gaidelio ir L. Apkalnio vargonų muzikoje [Prayer transformations in emigrant creation: gestures of catastrophic modernism in poetry of A. Mackus and organ music of J. Gaidelis and L. Apkalnis]. Menotyra. Studies in Art, 2013, vol. 20, no. 3, pp. 255-272.

13. Mackus, Algimantas. Poezija [Poetry]. Vilnius, 1972, 167 p.

14. Mackus, Algimantas. Trys knygos: Jo yra žemé. Neornamentuotos kalbos generacija. Chapel B. [Three books. His is the land. Generation of nonornamented language. Chapel B]. Vilnius, 1999, $172 \mathrm{p}$.

15. Milosz, Czeslav. Tévynès ieškojimas [Searching for homeland]. Vilnius, 2011, $275 \mathrm{p}$.

16. Modernism and Music. An Anthology of Sources. Ed. By Daniel Albright. Chicago, 2004, 428 p.

17. Tarasti, Eero. Signs of music : a guide to musical semiotics. Berlin, New York, 2002, $224 \mathrm{p}$.

\section{Suggested citation}

Landsbergyte-Becher J. The Secondary in Concept of Resistance and Processes of Modernism: Rethinking Baltic Minimalism. Pytannia literaturoznavstva, 2017, no. 95, pp. 130-145.

Стаття прийнята до друку 31.07.2017 p. 